\title{
Tingkat Kepuasan Infromasi Kuliner Terhadap Penggunaan Instagram @anakjajan
}

\author{
Veeren Monica Sanjaya, Gafar Yoetadi \\ Veerenmonica17@gmail.com,Gafars@untar.ac.id \\ Fakultas Ilmu Komunikasi, Univaersita Tarumanagara
}

\begin{abstract}
Over time, internet technology has become wider and easier. One of them is the development of social media, Instagram, which is the most widely used. In Instagram it is not only used for socializing and communicating, but now Instagram is a culinary information tool that is widely used by the public, especially for those who love culinary. As an example, there is a culinary account @anakjajan that has enough followers. The purpose of this studywas to determine the level of satisfaction of culinary information on the use of followers of @anakjajan's instagram. This study uses the uses and gratification theory, information satisfaction consists of information seeking, entertainment, personal identity, social integration and interaction and the use of Instagram social media, namely the amount of time, media content, and media relations with individuals. Research uses descriptive quantitative method approaches. The population used in this study is @anakjajan followers with 100 respondents. In this study the validity, reliability, normality, correlation coefficient, coefficient of determination, and t test were carried out. So it can be concluded from the results of the coefficient of determination there are 0.138, which means that the Culinary Information Satisfaction of 13.8\% on the Use of Instagram
\end{abstract}

Keyword : Information Satisfaction, Uses and Gratification, Use of Social Media

\begin{abstract}
Abstark
Seiring berjalannya waktu, teknologi internet semakin luas dan mudah. Salah satunya perkembagan media social yaitu Instagram yang paling banyak digunakan. Dalam Instagram tidak hanya digunakan untuk bersosialisasi, dan berkomunikasi, tetapi kini Instagram menjadi sarana informasi kuliner yang banyak digunakan oleh masyarakat khusunya bagi mereka pencita kuliner. Sebagai salah satu contohnya dengan adanya akun kuliner @anakjajan yang memiliki cukup banyak followers. Tujuan dari penelitian ini adalah untuk mengetahui tingkat kepuasan informasi kuliner terhdapa penggunaan Instagram para followers @anakjajan. Penelitian menggunakan uses and gratification, kepuasan informasi terdiri dari informasi seeking, entertainment, personal indentity, social integration and interaction dan penggunaan media social Instagram yaitu jumlah waktu, isimedia, dan hubungan media dengan individu. Penelitian menggunakan pendekatan kuantitatif metode deskriptif. Populasi yang digunakan pada penelitian ini followers @anakjajan dengan 100 responden. Pada penelitian ini dilakukan uji validitas, relibitas, normalistas koefisien korelasi, koefisien determinasi dan uji t. jadi kesimpulannya dari hasil koefisiein determinasi terdapat 0,138 yang artinya Kepuasan Informasi Kuliner sebesar 13,8\% terhadap Penggunaan Instagram.
\end{abstract}

Kata Kunci : Kepuasan Informasi, Uses and Gratification, Penggunaan Media Sosial

\section{Pendahuluan}

Komunikasi memiliki ikatan erat di dalam kehidupan manusia yang tentunya tidak dapat dipisahkan. Melalui kita bisa dapat melakukan pertukaran informasi, untuk mendukung kegiatan social-budaya, ekonomi, politik yang membutuhkan pemahaman bersama, demi tercapinya tujuan. Kini komunikasi semakin gampang 
untuk di jangkau, karena adanya teknologi memudahkan kita dalam berkomunikasai serta mendapatkan informasi secara cepat.

Seiring waktu berjalan, internet luas dan mudah. Tetapi adanya internet hadir bisa dikatakan telah telambat ada di Indonesia, namun dengan perkembangannya sangat cepat. Awal mula nya internet hanya tersedia di komputer, kini sudah ada di elektronik yang bisa dibawa seperti tablet, laptop, serta telepon genggam. Media Konvensional saat ini seperti televise, radio, koran telah di abaikan oleh masyarakat termasuk di Indonesia.

Dalam sistem internet, kelompok yang tersebar dalam lingkungan masyarakat maya yaitu kelompok keanggotannya didasarkan pada kebutuhan layanan atau website. Internet, produk teknologi yang banyak dimanfaatkan oleh masyarkat sebagai produk teknologi. Internet dengan itu dapat memuculkan jenis interaksi social baru yang berbeda dengan interaksi sebelumnya. Pada masa lampau, masyarakat berinteraksi secara face to face communication, dengan begitu masyarakat berinteraksi di dalam dunia maya atau dengan interkasi social internet.

Dengan munculnya internet dapat menghubungkan manusia dari berbaai belahan di dunia yang tidak saling terhubung, internet media social diperkenalkan menjadi media yang penting karena kehadirannya dapat membuat dampak perubahan besar dalam penyampain pesan.

Dalam pemikirin Boyd, definisi social media sebagai perangkat lunak yang memungkinkan perorangan untuk bergabung, berbagai, berkomunikasi, dalam kasus terentu bisa saling berkolaborasi atau juga bermain. Social media kekuatan pada user-generated content di mana konten tersebut dapat dihasilkan oleh pengguna bukan oleh editor sebagimana di institusi media massa.

Di social media, informasi menjadi system yang padu. Informasi menjadi entitas yang penting dari social media. Karena tidak seperti media-media yang lainya di internet, pengguna social media mengkreasikan repsentasi identitasnya, memprodukasi content dan melakukan interkasi berdasarkan informasi yang ada.

Perkembangan social media yang berkembang saat ini yakni Instagram. Instagram ialah salah satu social media yang paling sering di akses oleh masyarakat. Dalam 60k di Instagram sudah 67k photos uploaded terbukti bukan kalau Instagram banyak diminati.

Dengan adanya social media, memudahkan masyarakat untuk mencari informasi kuliner yang ada di Jakarta. Salah satunya akun kuliner @anakjajan dengan memiliki followers 323.000 per tanggal 19 February 2019.

Para followers terinspirasi oleh anakjajan untukmencoba berbagai kuliner yang hits dan lezat. Setiap harinya @anakjajan memberikan informasi kuliner dengan memposting di Instagram. Di dalam postingan tersebut yang di upload oleh @ anakjajan informasi yang diberukan cukup mendetail. Sebagai contoh, tempat makan yang sudah mereka datangi,. Sehingga followers-nya yang penasaran akan ikut mencicipinya.

Penulis juga ingin membuktikan dengan meneliti penelitian ini, apakah adanya kepuasan informasi kuliner terhdapa penggunaan Instagram @anakjajan di Jakarta. Oleh sebab itu, sesuai dengan pembahasan di atas, dengan judul : Tingkat Kepuasan Informasi Kuliner terhadap Penggunaan Instagram @anakjajan. 
Di bawah ini merupakan teori yang digunakan oleh penulis :

\section{Menggunakan \& Gratifikasi}

Asusmsi tersirat sebagai yang di arahkan, karena dengan adanya pengguna media hanyalah salah satu cara untuk memenuhi kebutuhan psikologis, efek media juga di anggap sebgai situai ketika kebutuhan terpenuhi.

Pertama periset mengkur Gratification Sought dan Gratification Obatained. Dari ini bisa di lihat bahwa periset dapat mengetahui kepuasan khalayak berdasarkan kesejangan antara GS \& GO. Dengan kata lain, kesenjangan kepuasan (discrepancy gratifications) perbedaan perolehan kepuasan yang terjadi antara score GS \& GO dalam mengkonsumsi media tertentu. Semakin kecilnya discrepancy, maka semakin memuaskan media tersbut.

Konsep GS \& GO. Gratification Souught : motif yang mendorong seseorang untuk mengonsumsi media.

Apabila gratification obtained : kepuasan yang nyata yang di peroleh seseorang setelah dia mengonsumsi suatu jenis media tertentu. ( Rachmat Kriyantoo, 2006:206-207)

Kepuasan Infromasi :

A. Tingkat kepuasan nyata yang telah di peroleh seseorang setelah mengkonsumsi media tersebut. Tingkat kepuasaan dapat di ukur berdasarkan 4 motif kebutuhan sesuai pemikiran McQuail, yakni :

I. Pencarian Informasi

Pengguna isi media untuk mengetahui / mencari informasi-informasi yang bersifat umum.

II. Identitas Pribadi

Menggunakan isi media untuk memenuhi kebutuhan identitas pribadi

III. Integrasi dan Interaksi Social

Media berisi untuk memperkuat hubungan social \& juga kegiatan masyarakat

B. Penggunaan Social Media

Kegiatan dalam melakukan / memakai seseuatu contohnya sarana / juga barang. Berdasarkan pemikiran Ardianto yang bukunya bejudul Komunikasi Massa, tingkat penggunaan media dapat dilihat dari frekuensinya dan juga durasi dari penggunan medianya.

Penggunaan media oleh individu dapat dilihat dengan 3 hal yakni :

a. Jumlah waktu, berkaitan dengan frekuensi yang ada, intensitas, serta durasi yang digunaka untuk mengakses sebuah situs;

b. Isi media, cara yang tepat supaya pesan bisa di sampaikan \& di komunikasikan sangat baik.

c. Hubungan media dengan individu yakni keterkaitan pengguna dengan social media

\section{Metode Penelitian}

Penelitian yang diteliti oleh peneliti menggunakan metode kaunatitatif (deskriptif ). Metode kuantitatitatif bisa sebagai metode positif. Secara gambaran umum, metodenya lebih spesifik, jelas \& rinci. Karena dapat dikuantitastikan berupa angka-angka (Sugiyono 2017:9)

Proses penelitian yang di gunakan deskripstif ialah dilakukan untuk mengetahui nilai variebl mandiri, baik 1 variabel / lebih (inependen) tanpa 
membuat suatu perbandinga, / menghubungkan antara variable 1 dengan yang lain. (Sugiyono 2013:3)

\section{Hasil Temuan dan Diskusi}

Table I Hasil Korelasi Koefisien (R) Kepuasan Informasi (X)

\begin{tabular}{c|c|c} 
& $\mathrm{R}$ & $\mathrm{R}^{2}$ \\
\hline $\begin{array}{c}\text { Kepuasaan informasi } \\
\text { terhadap penggunaan } \\
\text { Instagram }\end{array}$ & 0,218 & 0,138 \\
Sumber : Data di dapat dengan SPSS
\end{tabular}

Table II Hasil Uji Test Of Signicant (t ) Kepuasan Informasi (X)

\begin{tabular}{c|c|c|c} 
& \multicolumn{3}{|c}{ Kepuasaan informasi terhadap penggunaan Instagram } \\
\hline I & 2,215 & $\mathrm{t}$ & 11,911 \\
\hline II & 0.29 & Sig & 0.000 \\
& Sumber : Data di dapat dengan SPSS
\end{tabular}

Penjelasan :

a. Dengan table yang menunjukkan hasil koefisien determinasi dengan menggunakan nilai $\mathrm{R}$ Square $\left(\mathrm{R}^{2}\right)$ sebesar 0,138 yang artinya bahwa dengan kemampuan varibel Kepuasan Informasi (X) dalam menjelaskan varibel dependen Penggunggunan Instagram (Y) sebesar 13,8\%, sedangkan sisanya $86,2 \%$.

b. Table II, menunjukkan hasil t untuk variabel Kepuasan Informasi dengan melihat nilai t sebesar 2,215 dan signifikan (sig) sebesar 0.000. Artinya Sig. hitung $<0.05$ yaitu $0.000<0.05$. Dengan begitu menunjukkan bila Ha di terima, bahwa variabel X secara individual memiliki Penggunaan Instagram Y.

Di lihat dari hasil uji hipotesis (t) di antara kedua variabel Kepuasan Informasi $\mathrm{X}$ dan Penggunaan Instagram Y menunjukkan hasil yang rendah, yaitu kepuasan informasi dari Instagram @anakjajan memiliki tingkat kepuasan terhadap penggunaan media social Y.

Hal ini dapat di sesuaikan dengan adanya Hipotesis (Ha) yaitu terdapat tingkat kepuasan informasi kuliner terhadap penggunaan Instagram @anakjajan. Bahwa artinya, semakin tinggi tingkat informasi kuliner yang diberikan maka juga semakin banyak tingkat kepuasan informasi terhadap penggunaan media social.

Berdasarkan hasil (R), tingkat kepuasan informasi terhadap penggunaan Instagram termasuk kategori rendah, dengan 0,218.

Kemudian dapat di lihat hasil ( $\mathrm{R}^{2}$ ), di ketahui bahwa Kepuasan Informasi $\mathrm{X}$ terhadap Penggunaan Media Sosial Y 13,8, sedangkan sisanya 86,2\% yang merupakan faktor lain tetapi tidak di bahas di penelitian ini. Maka disimpulkan bahwa Instagram @anakjajan merupakan salah satu media social yang memiliki tingkat kepuasan terhadap penggunaan Instagram. Sehingga dengan begitu followers dapat mengetahui informasi kuliner yang sedang hits di kalangan penyuka kuliner 
Veeren Monica Sanjaya, Gafar Yoetadi :Tingkat Kepuasan Infromasi Kuliner Terhadap Penggunaan Instagram@anakjajan

\section{Kesimpulan}

Hasil peniliti yang telah di uji dengan statistic, dapat di simpulkan sebagai berikut:

1. Dengan melihat hasil $\mathrm{R} 0,218$, yang di mana artinya hubungan antara $\mathrm{X} \& \mathrm{Y}$ dapat di katakan rendah karena informasi kuliner yang di sajikan kurang mendetail serta juga kurang memuaskan.

2. Melihat hasil uji ( $\left.\mathrm{R}^{2}\right) 0,138$, yang di mana artinya bahwa kepuasan informasi kuliner 13,8\% terhadap penggunaan Instagram.

Dengan adanya penelitian ini, terdapat tingkat kepuasan informasi kuliner terhadap penggunaan Instagram @anakjajan. Itu artinya semakin banyak tingkat informasi yang di berikan maka juga semakin tinggi tingkat kepuasan informasi terhadpa penggunaan Instagram. Sebagai contoh bukti pernyataan yang telah di jawab oleh responden pernyataan no 14 yang terdiri 4 pernyataan \& sebagian besar mereka setuju bahwa setelah mengakses Instagram @anakjajan mampu meberikan informasi kuliner.

\section{Ucapan Terimakasih}

Saya panjatkan serta ucapakan Puji dan Syukur kepada Tuhan Maha Esa, karena telah melimpahkan berkat \& rahmatnya-Nya, sehingga penulis dapat menyelasaikan penelitian ini.

Saya menyadari bila penyusunan jurnal ini tidak akan bisa terwujud tanpa adanya bantuan \& dorongan dari berbagai pihak. Oleh sebab itu, dengan adanya kesempatan ini saya juga ingin menyampaikan banyak terimakasih kepada yang terhormat :

1. Ibu Dr. Riris Loisa, M.Si. selaku Dekan dan Pembantu Dekan I Bidang Akademik dan Kemahasiswaan Fakultas Ilmu Komunikasi Universitas Tarumanagara

2. Bapak Yugih Setyanto S.sos.M.si. selaku Wakil Dekan Fakultas Ilmu Komunikasi Universitas Tarumanagara.

3. Ibu Sinta Paramita S.I.P.,M.A. Selaku Kaprodi Fakultas Ilmu Komunikasi Universitas Tarumanagara.

4. Bapak Drs. M. Gafar Yoetadi, M. Si selaku dosen pembimbing skripsi yang senantiasa membantu dan membimbing penulis dan selalu meluangkan waktunya untuk dapat membimbing penulis. Tanpa beliau, penulis tidak akan mampu menyelesaikan skripsi ini tepat waktu.

5. Seluruh Dosen Fakultas Ilmu Komunikasi Universitas Tarumanagara yang telah memberikan bekal ilmu dan pengetahuan yang bermanfaat bagi saya.

6. Kepada keluarga yang selalu memberi dorongan, semangat, motivasi, serta selalu mendoakan saya dalam menyelesaikan tugas-tugas baik dari perkuliahan.

7. Serta kepada teman dan sahabat penulis yang telah memberikan semangat kepada penulis hingga bisa menyelesaikan skripsi sampai selesai.

8. Teman-teman mahasiswa/I satu Fakultas yang banyak membantu saya dan memberikan dukungan dalam proses penyusunan proposal skripsi hingga selesai.

Semoga segala bimbingan dan bantuan yang telah diberikan kepada saya dapat saya gunakan dengan sebaik-baiknya oleh saya. saya menyadari bahwa masih banyak kekurangan dalam penyusunan laporan skripsi ini baik dalam teknik penyajian materi maupun pembahasan. 
Akhir kata semoga skripsi ini dapat bermanfaat dan memberi inspirasi serta dapat menjadi referensi yang berarti bagi pihak yang membutuhkan.

\section{Daftar Pustaka}

Ardianto, Elvinaro, dkk. (2007). Komunikasi Massa (edisi revisi) Suatu Pengantar. Bandung: Simbiosa Rekatama Media

Afif Fuadi (2018). Penggunaan Instagram dan Tingkat Pemenuhan Kebutuhan Informasi

Sugiyono (2017). Metode Penelitian Kuantitatif, Kualitatif dan R\&D. Bandung: Alfabeta

Nasrullah, Rulli (2015) Perspektif Komunikasi Budaya dan Sosioteknologi. Jakarta: Simbiosa Rekatama Media

Krisyantono, Rachmat (2006) Teknik Praktis Riset Komunikasi. Jakarta: Kencana 